\title{
Amalgamation of Icelandic Municipalities, Average Cost, and Economic Crisis: Panel Data Analysis
}

\author{
Vífill Karlsson \\ The Faculty of Business and Science, University of Akureyri \\ Sólborg/Norðurslóð, 600 Akureyri, Iceland \\ Tel: 354-695-9907Ｅ-mail: vifill@unak.is \\ Dept. of Regional Development \\ The Federation of Municipalities in West-Iceland \\ Bjarnarbraut 8, 310 Borgarnes, Iceland
}

Tel: 354-433-2314 E-mail: vifill@ssv.is

$\begin{array}{ll}\text { Received: December 9, } 2014 & \text { Accepted: January12, } 2015 \quad \text { Published: April 4, } 2015 \\ \text { doi:10.5296/ijrd.v2i1.7531 } & \text { URL: http://dx.doi.org/10.5296/ijrd.v2i1.7531 }\end{array}$

\begin{abstract}
This study investigated the amalgamation of the municipalities in Iceland and its impact on expenses, classified by 12 different affairs. An earlier paper suggested that the average cost is lower for larger municipalities than for smaller ones in Iceland. The present study, however, tested whether the average cost of municipalities becomes lower following their amalgamations by implementing a new approach. Instead of estimating the presence of scale economies, dummy variables are used to detect the changes of average cost following the amalgamation. With this approach, the analysis separates effects traced to ordinary population change from population change caused by municipality amalgamations. Furthermore, it also tested the impact of municipality geographical size (in $\mathrm{km}^{2}$ ), local population, distance from Reykjavík, and number of urban communities within each municipality on the average cost. Since the data include several years prior to the economic crisis in 2008 and several years after, it was feasible to test the real return of the local government retrenchment because of the crisis. The prior study was implemented on data for average cost of all municipalities' affairs in the year 2006. The present study was based on the average cost for all municipalities' affairs during the period of 2004-2010. Panel data analysis was implemented. The paper suggests that the average cost has become lower following amalgamations in
\end{abstract}


industrial and cultural affairs. Those affairs, however, only generate about 5\% of municipalities' total costs. Accordingly, the impact is thus rather limited in terms of cost. Moreover, larger municipalities have lower average cost than smaller ones in all affairs except for social service.

Keywords: Municipalities, amalgamation, average cost, economic crisis

\section{Introduction}

The literature for the amalgamation of municipalities has been dominated by estimates of scale economies - larger municipalities should be more efficient than smaller ones and in a better shape to run new public programs e.g., when the central government wants to decentralize the government sector. Amalgamation reduces average cost for the municipalities while the average income should be relatively stable, since it correlates highly with population income. Furthermore, larger municipalities should be able to provide better services, since they have access to a larger labour market and are thus more likely to hire appropriate staff, which is a significant issue for specialised services. Presently, the bulk of public services is provided by the central government in Iceland, while their vast majority is supplied by local government in other Nordic countries (Kristinsson, 2001).

Despite a couple of attempts, however, studies have not detected lower average cost following an amalgamation of municipalities, although a recent paper suggested that the average overhead cost of municipalities would decrease following an amalgamation (Vífill Karlsson \& Jónsson, 2011-2012). Another work of research indicated that the overall operational benefit generated by municipal amalgamation would be instantly used to increase the municipality service level (Eypórsson \& Jóhannesson, 2002, p. 262). Therefore, it is relevant to investigate further whether the amalgamation of municipalities has reduced their average cost.

The possible impact of municipality amalgamation in Iceland on average cost was investigated by a method similar to that used when the presence of scale economies is tested, referred to in the paper mentioned above (Vífill Karlsson \& Jónsson, 2011-2012). Here it is assumed that, if average cost were significantly lower following a population increase, an amalgamation would return reduced average cost. The approach was a cross section regression analysis of data for all municipalities in Iceland in 2006 (79) by which the average cost of municipalities of all sizes was compared. This method, however, is limited in application to the question at hand. It estimates the average cost with respect to population density, since the population changes without any alterations to municipality size in terms of square kilometres or adjustments in administration borders. Municipality amalgamation, however, includes a population increase and an expansion in geographical size as well - that is, population density would not be affected by municipality mergers unless these attracted new migrants, which is not the issue here. Thus, the method used in the previous study does not capture the true impact of a municipality amalgamation since it does not answer the question of whether a larger administration unit is more efficient than a smaller one in serving a dispersed population. 


\section{Macrothink}

This research improves the methodological limits of the prior study by investigating whether average cost has decreased significantly following an amalgamation compared to municipalities that did not amalgamate. This is possible by implementing a panel data sample for all municipalities in a certain period; here, the data comes from Iceland and applies to the period of 2004-2010. Furthermore, it was possible to estimate the impact of other relevant factors on municipalities' average cost such as local population, urban structure, municipalities' land size, and the effect of the financial crisis in 2008.

The organization of the study is as follows. Section 1 includes an introduction and description of the paper's purpose as well as outlining the construction of the research question. In Section 2, the theoretical background and a short overview of recent literature is provided. Section 3 comprises a theoretical discussion of the model. Section 4 focuses on the data sources, as well as the definition, and construction of the data. Section 5 contains the analysis and results, while Section 6 includes a summary and concluding remarks.

\section{Municipalities of Iceland}

There is a two-tier system in Iceland: the central level, with central government, and the local level, comprising municipalities. Counties are not part of the current system, although the role of counties was historically important. Local government share in government purchases has been approximately 1/3, or 32\% in 2010 (Eypórsson, Glösen, \& Karlsson, 2014, p. 39) while, for comparison, this has been around 2/3 in other Nordic countries (Kristinsson, 2001, p. 46). Total public spending as a share of gross domestic product (GDP) was close to $50 \%$ in 2010, having grown from 35\% in 1980 (Eypórsson et al., 2014, p. 37).

Municipalities have existed longer than the state in Iceland - and can even be traced back to the 10th century. From early centuries, social affairs, especially regarding the poorest part of the population, industrial concerns - mainly sheep farming, and real estate insurance have comprised their most comprehensive services in terms of expenses (Snævarr, 1993, p. 322). Thereof, financial assistance to the poorest has been the largest item as regards relative cost (Jónsson \& Magnússon, 1997, p. 740). Today, the most extensive affair of Icelandic municipalities with regard to expenditure per capita is education when the COFOG classification is applied. The second most comprehensive cost item is social protection, with recreation \& culture and religion in third place (Eypórsson et al., 2014, p. 58).

Table 1. Number of amalgamations in Iceland since 1950

\begin{tabular}{|c|c|c|}
\hline Year & Number of amalgamations & Number of merged municipallities \\
\hline 1953 & 1 & 2 \\
\hline 1964 & 1 & 2 \\
\hline 1971 & 1 & 2 \\
\hline 1972 & 2 & 4 \\
\hline 1984 & 1 & 2 \\
\hline 1986 & 1 & 2 \\
\hline 1987 & 3 & 9 \\
\hline 1988 & 2 & 4 \\
\hline
\end{tabular}




\begin{tabular}{|c|c|c|}
\hline 1989 & 1 & 2 \\
\hline 1990 & 5 & 14 \\
\hline 1991 & 2 & 5 \\
\hline 1992 & 3 & 7 \\
\hline 1993 & 1 & 2 \\
\hline 1994 & 13 & 38 \\
\hline 1995 & 1 & 3 \\
\hline 1996 & 1 & 6 \\
\hline 1997 & 1 & 3 \\
\hline 1998 & 12 & 51 \\
\hline 2001 & 5 & 15 \\
\hline 2002 & 5 & 12 \\
\hline 2003 & 1 & 2 \\
\hline 2004 & 4 & 13 \\
\hline 2005 & 2 & 8 \\
\hline 2006 & 7 & 17 \\
\hline 2008 & 1 & 2 \\
\hline 2009 & 1 & 2 \\
\hline 2010 & 1 & 2 \\
\hline 2012 & 2 & 233 \\
\hline Total & 81 & 12 \\
\hline & A & \\
\hline
\end{tabular}

Source: The Association of Local Authorities in Iceland.

Municipalities probably numbered 163 in 1703 . When Iceland became part of the Danish Crown in 1662, the role of municipalities as service providers was diminished and in 1809 they were completely abolished. In the year 1872 municipalities were re-established in accordance with new legislation and their number gradually increased again. (Eypórsson, 1998, pp. 9-11) Municipalities in Iceland reached a maximum in 1950 when they were 229. ("Breyting á sveitarfélagaskipan á Íslandi frá 1950,"). From then onwards, their number remained stable until a wave of municipal amalgamations arose in the mid 1980s (Kristinsson, 2001, p. 28) reaching a climax in 1994 and 1998 (Table 1). In 80 amalgamations since 1950 the number of municipalities was reduced to 75 in 2012, apart from one municipality which was abolished ("Breyting á sveitarfélagaskipan á Íslandi frá 1950,") as a result of having lost its entire population. Municipal mergers have always been voluntary in Iceland. There were 74 municipalities in Iceland in 2013; only six of those had more than 10000 inhabitants, more than half less than 1000 and a third under 500 (Eypórsson et al., 2014, pp. 17-22). The average population of Icelandic municipalities is approximately 4179 and their average geographical area is 1392 square kilometres. Thus, in a European context they are small in terms of the former and large in terms of the latter (Vifill Karlsson \& Jóhannesson, 2014, p. $18)$.

When this trend in amalgamations is compared to the development of municipal expenditures per capita, that has been gradually increasing, at least during the period 1980-2012 (Eypórsson et al., 2014, p. 42), and there are no signs of changes in the pattern of expenditure 
close to the years of massive amalgamations in 1994 and 1998. A short overview shows that two tasks from central government have been transferred to the municipalities: the primary school in 1998 and affairs of the disabled in 2011.

\section{Literature Review}

Several studies have focused on the direct impact of the amalgamation of municipalities on their operational cost in providing local services. Grétar Pór Eypórsson and Hjalti Jóhannesson (2002, p. 261) argued that the possible gains in terms of lower cost have been instantly spent on improved services. Moisio and UUsitalo (2013) compared the development of the average cost of amalgamated and non-amalgamated municipalities in Finland during the period 1970-1981 and concluded that average cost increased in the merged municipalities in all expense categories except for overhead cost. These amalgamations were voluntary. The overhead cost reduction was lower than the increase in other expense categories. Note that even ten years after the amalgamations, the cost of the merged municipalities still remained higher than that of the non-merged. Lüchinger and Stutzer (2002) did not detect any municipal economies of scale. Rouse and Putterill (2005) did not succeed in proving that the amalgamation of municipalities resulted in efficient road maintenance. Moreover, several studies did not detect scale economies or any other evidence for lowered cost following an amalgamation of municipalities (Byrnes \& Dollery, 2002; Dollery, Byrnes, \& Crase, 2007; Dollery, Crase, \& Johnson, 2006). Furthermore, a larger municipality is not necessarily more cost-efficient than a smaller one; collaboration between municipalities is more likely to enhance operational efficiency than amalgamation (Dollery et al., 2006). A new Danish study, based on a large amalgamation process in the year 2007, when the number of municipalities dropped from 271 to 98 , suggested that larger municipalities are not more cost efficient than smaller ones (Houlberg, 2011). Note that only overhead cost was included in the analysis. An even newer unpublished study (Blom-Hansen, Houlberg, \& Serritzlew, 2011) of the same case in Denmark suggested, however, that the mergers resulted in a considerable cost reduction - approximately $8 \%$ of their total cost and a recent Icelandic study (Vífill Karlsson \& Jónsson, 2011-2012) indicated that, among all municipality affairs, overhead cost was most likely to be lowered following an amalgamation. Another research study on data from Israel (Reingewertz, 2012) concluded that municipal mergers in 2003, where the number of municipalities was reduced from 264 to 253 , resulted in a $9 \%$ cost reduction and no evidence was found of deteriorating service levels.

An investigation of voluntary and compulsory mergers was conducted in a German study (Blesse \& Baskaran, 2013). Their estimate showed that municipal cost, i.e. overhead cost, decreased following a merger, but to a much smaller extent in case of voluntary mergers. Moreover, with the passing of time, the cost tends to increase in case of voluntary mergers while it decreases for compulsory ones. The authors recommend further investigation into the matter in order to find reliable explanations for those results. According to the authors, one of the reasons could be that municipalities that join voluntary mergers are generally fiscally weaker than those involved in compulsory amalgamations and have already rearranged their business operations. 
According to Fox and Gurley (2006) it would be preferable to be able to conclude that amalgamating municipalities is a good policy. This is, however, not possible since the evidence from a vast variety of studies both supports and undermines that gesture. This seems to be in line with present review. However, a new perspective regarding voluntary and compulsory amalgamations might shed some light on this discrepancy since many of the successful mergers are of the compulsory type and voluntary amalgamations appear to be less successful. Much more extensive research is needed, however, to determine this question; something which is beyond the purpose of this paper.

Other impacts of municipal amalgamation have been detected. Tyrefors Hinnerich (2009) showed that municipalities were likely run into higher debts in the antecedents of amalgamation and thus become free riders in the new merged municipality. Moreover, the smaller the municipality (relatively), the more likely it would be to generate that behavioural pattern. This finding is in agreement with Jordahl and Liang (2010) and Blom-Hansen (2010). However, by conducting a special operation, the Japanese authorities have been able to modify this behavioural trend (Nakazawa, 2013). A related topic was presented by Dur and Staal (2008) who stated that small municipalities became free riders due to the proximity of another larger urban area. If a small rural municipality is close to a city in another municipality that offers a vast variety of both private and public services, the city would serve the inhabitants in both municipalities, and the local government of the small municipality would not provide the services due to lack of pressure from the local community. When or if those communities merge, the service level of the small community will still be low or possibly lower, according to Eythorsson and Johannesson (2002, p. 261), due to the weak democratic impact of the smaller participant of the amalgamation.

Amalgamations of municipalities can bring other challenges. Dahl (1967) pointed out that democracy was much weaker in larger communities than in smaller ones because of limited access to local politicians and the authorities. This is not in line with Newton (1982), who claimed that large government units are no less democratic than small ones because they are able to provide a wider variety of services than smaller entities. Thus, the civilians of smaller municipalities have to obtain the missing services from other municipalities - services provided by local authorities that have been voted into power by others. Nielsen (2003), on the other hand, concluded that municipality amalgamation had a negative impact on democracy; it would be best to restrict the size and structure of municipalities to one dominant urban area. This research is based on data relating to municipal amalgamation in Sweden during the period 1952-1974.

The provision of public service can generate economies of scale. Rosen (2008) suggested that scale economies were present in public services such as in fire departments and libraries. Similar results were addressed in a general British study, in which scale economies were present in health care services, water supplies, and telecommunications (Burridge, 2008). Furthermore, scale economies were present in primary and upper secondary schools, both regarding overhead and teaching cost. However, diseconomies of scale became present in teaching when quality was taken into account. Similar results were found by Duncombe and Yinger (2007) and Duncombe et al. (1995). Therefore, the results are mixed when it comes to 
scale economies in the provision of public services, especially considering whether amalgamation of municipalities would generate any financial gains in terms of lower average operational costs.

Even though empirical studies do not provide clear evidence of decreased cost following municipal amalgamation or even a presence of scale economies in the provision of public services, the theory suggests that at least the service provision should generate scale economies, albeit to a limited extent. It has been argued that an urban population contributes to social benefit in terms of agglomeration economies. "In the presence of agglomeration economies, average production cost is generally lower, which in knowledge-based industries increases profits, returns to shareholders, and the real wages of highly skilled labour" (Vifill Karlsson, 2012, pp. 125-126). So, agglomeration economies are similar to scale economies in that they are a source of economic growth and higher welfare. An urban population contributes to social cost as well, since additional citizens increase traffic congestion, air pollution, etc. When the population increases, the benefit grows regressively while the cost increases progressively, and thus each community has a global maximum of net benefit with respect to a local population. (O'Sullivan, 2009, pp. 235-240)

There are several discrepancies when it comes to the financial return of municipal amalgamation or even the financial viability of small units. The contribution of this paper is to detect the financial return of municipal amalgamation by implementing a new method to analyse a robust data sample from Iceland. This data sample is also unique since the municipalities are so small in terms of population.

\section{The model}

The Cobb-Douglas function is assumed to be appropriate to all municipalities' cost structure for affairs; i.e. it allows factor substitution. Accordingly, if there are two factors, labour, $x_{1}$, and capital, $x_{2}$, used to produce and/or provide one product such as a social service, the following cost minimization problem will occur (Varian, 1992, p. 54):

$$
c(w, r, y)=\min _{x_{1} x_{2}} w x_{1}+r x_{2} .
$$

Total cost is a function of two variable production factors: labour and capital. The total cost is minimized by changing the number (or the amount) of the production factors with respect to their cost, wages $(w)$, and interest rates $(\boldsymbol{r})$ and how they will affect the production as covered by the following constraint of the cost minimization problem:

$$
A x_{1}^{a} x_{2}^{b}=y .
$$

As noted in an earlier paper on the matter (Vífill Karlsson \& Jónsson, 2011-2012), the Cobb-Douglas function was developed and constructed for conventional production, such as screws, beans, and bread, that are much easier to measure than service. In the case of service, as in the present study, it is difficult to quantify the output. For simplicity, it is common to count the customers and assume that every one of them gets identical service, both in quantity and quality. This is unrealistic but necessary because of limited data.

The model is generalized and will be implemented on all municipal affairs. According to 
model (2), production is found by multiplying the production factors and an unspecified constant, $A$. By assuming that the constant is equal to 1 and the production function is characterized by constant return to scale, $a+b=1$, the model becomes simple for total cost dependent on factor cost, output quantity, and an unspecified constant, $K$,

$$
c(w, r, y)=K w^{a} r^{1-a} y,
$$

where $K=a^{-a}(1-a)^{a-1}$. Scale economies can be traced both from the function of total cost (Burridge, 2008; Heathfield \& Wibe, 1987) and average cost (Schure \& Wagenvoort, 1999). Average cost, $c(w, r, y) / y$, was chosen for the present paper analysis as well as a dummy variable (s) to estimate the municipalities' amalgamation effect on average cost. If scale economies are not present, $a+b \neq 1$, Eq. 3 suggests that increased output will have no impact on total cost.

$\frac{\partial\left(\frac{c(w, r, y)}{y}\right)}{\partial y}=0$

If, however, scale economies are present, $a+b>1$, the partial derivative of average cost with respect to output will be negative,

$\frac{\partial\left(\frac{c(w, r, y)}{y}\right)}{\partial y}=\left(\frac{1-a-b}{a+b}\right) N y^{\left(\frac{1-a-b}{a+b}\right)-1}<0$,

since the first factor is negative and the second is positive. A municipal amalgamation increases population. It is, however, necessary to separate this type of population increase from population changes traced to ordinary migration without any extension of the land area or borders. Amalgamation cancels former municipalities and returns a new municipality of a larger population than its predecessors without any migration and changes in population density, because the populations of the former municipalities have not changed, at least not instantly. Amalgamation only changes administrative boundaries, and could enhance operational efficiency because of the potential presence of scale economies. However, as indicated earlier, not all municipal affairs that include scale economies will return a significantly lower average cost following an amalgamation, because many services must be provided close to the homes such as waste disposal, sewage, and snow removal. Besides, the geographical distribution of particular services cannot be changed; e.g., primary schools, playschools, and matters of disabilities.

Municipal amalgamations must be labelled in a special way in the empirical model in order to be able to separate their possible impact on average cost from the effect of real population increase on average cost (scale economies). Changed administration boundaries, $S$, have an impact on the model's constant term, $K$, in the theoretical model, because they capture all regular impacts on average cost other than those that are represented by the endogenous variables, such as wages, interest rates, and output quantity (here the local population represents production quantity since the production is a service as argued earlier). Therefore, the partial derivative of average cost with respect to administrative boundaries must be negative, 
$\frac{\partial\left(\frac{c(w, r, y)}{y}\right)}{\partial S}=\frac{\partial\left(\frac{c(w, r, y)}{y}\right)}{\partial K} \frac{\partial K}{\partial S}<0$,

if changes would lead to structural reform and thus decrease average cost (where the first factor is positive and the second, $\partial K / \partial S$, could be negative); that is one possible answer to the research question of the present paper. The empirical model is based on the following theoretical model,

$c_{i t}=\alpha_{i}+w_{i t} \beta_{1}+r_{i t} \beta_{2}++z^{\prime}{ }_{i t} \beta_{3}+d^{\prime}{ }_{i t} \beta_{4}+\varepsilon_{i t}$.

where the average cost, $c$, in each municipality, $i$, for each year, $t$, is determined by wages, $w$, interest rates, $r$, and a vector of relevant additional explanatory variables, $z$. The output is the public service provided to the citizens that live in various municipalities. Since the municipalities vary in geographical area (i.e. size in terms of square kilometres), number of urban communities, and proximity to the capital area, and the level of those factors can change the need for services, they were included among the explanatory variables. A selected number of dummy variables, $d$, such as municipal amalgamations and time dummies, were also included. Further discussion regarding the variables is found in the chapter that discusses the data. The time dummy variables capture all potential macroeconomic impacts, such as changes in interest rates, economic growth, and currency value. Therefore, a special explanatory variable for interest rate was not needed. Log-normal function will be implemented:

$$
\ln c_{i t}=\alpha_{i}+\ln w_{i t} \beta_{1}+\ln r_{i t} \beta_{2}++\operatorname{lnz}_{i t}^{\prime} \beta_{3}+d^{\prime}{ }_{i t} \beta_{4}+\varepsilon_{i t} .
$$

Since some of the explanatory variables contain zero values, an inverse hyperbolic sine will be calculated for all values instead of a natural logarithm in order to keep the maximum numbers of observations. This is a fixed-effect panel data model.

The present model (4) is comparable to the model used to analyse scale economies. A model of stochastic frontier is most commonly used to detect the presence of scale economies. This model estimates a line that corresponds to the shape or the trend of the population's upper (or lower) fringe in the data set. The model above, however, returns a line which is the best linear unbiased estimation that runs through the centre of the data sample - a traditional regression analysis. Since the purpose of the study is to detect whether the average cost of municipalities decreases following an amalgamation, a traditional regression analysis is more appropriate than the stochastic frontier. This is because it is only interesting to test whether the average cost of the merged municipalities changes significantly with respect to municipalities that did not merge rather than testing whether the municipal amalgamations had a significant impact on the stochastic frontier as such. Therefore, a fixed-effect panel data model will be used instead of the stochastic frontier.

Since the characteristics of the cost can vary widely between types of affairs, 11 different models will be used, instead of running one model for the total cost of municipalities. An increased likelihood of missing data variation would have occurred if the analysis had been based on total cost only. 


\section{Data}

The data was the average cost for each year during the period of 2004-2010. The yearbook of the Association of Local Authorities in Iceland was the source of this data. The numbers were classified according to the following 12 different affairs of the local government:

1. Overhead cost

2. Social services

3. Health care

4. Education

5. Culture

6. Sports and youth welfare

7. Fire department and public disaster protection

8. Hygiene

9. Traffic and transportation

10. Environmental affairs

11. Planning and construction

12. Industrial affairs

The average cost for every affair is found by dividing its total cost, $e$, by the local population, $m$. The numbers were provided for each of the 12 different affairs, $g$, for every municipality, $i$, and all years, $t$, in the period of 2004-2010. Price values of all years were corrected for inflation by the following index, $p_{2008} / p_{t}$, so that all are shown in terms of price level in 2008. Therefore, the overall calculation of the average cost was as follows:

$c_{g i t}=\left(\frac{e_{g i t}}{m_{i t}}\right)\left(\frac{p_{2008}}{p_{t}}\right)$.

Since some of the smallest municipalities did not have any expenses in some cases and the qualities of the log-normal function were preferable - such as lower risk of heteroskedasticity and the coefficients as relative numbers - the inverse hyperbolic sine was calculated for all of the numbers in order to keep zero values and thus all observations. Therefore, the following was applied in the final stage of the calculations:

$c_{\text {git }}^{\text {ihs }}=\sinh ^{-1}\left(c_{\text {git }}\right)=\ln \left(c_{\text {git }}+\left(1+c_{\text {git }}^{2}\right)^{1 / 2}\right)$.

The data for the local population and the number of urban communities came from Statistics Iceland. The local population is based on 1st December of each year. Numbers for the size of geographical area of municipalities were obtained from the National Land Survey of Iceland. Since a large part of Iceland is highlands unsuitable for residence, the numbers for the size of municipality area were revalued by discarding all land higher than 200 meters above sea level, as argued in another regional study for Iceland (Vifill Karlsson, 2011).

Travel time to Reykjavík (centre of the capital area) was found by collecting road distances between all localities in Iceland and Reykjavík. The share of asphalt roads (paved roads) and gravel roads was calculated between each locality and Reykjavik, where the average speed on 
a paved road was assumed to be 90 kilometres per hour and 70 kilometres per hour on gravel. The travel distance was then transformed into travel time in the above speed terms. Accordingly, the average travel time between each municipality and Reykjavík was calculated.

Dummy variables for municipal amalgamations were constructed. Each dummy variable covered a certain type of amalgamation. The types of classification were based on two factors: the similarities of the municipalities that joined the merger and their number. The municipalities were assumed to be similar if their populations were all only counted either by tens, hundreds, or thousands and not if they were counted in both tens and hundreds or hundreds and thousands. Then the amalgamation was also classified by the number of the municipalities that joined the merger - that is either two, three, or four municipalities in each amalgamation. The classification returned both better estimates and opportunities for a clearer insight into the impact of municipal amalgamation on their cost. The number of mergers in each classification was 1 to 4 in the period of 2004-2010 (Table 2).

Table 2. Number of municipality mergers in each classification type

\begin{tabular}{|l|c|c|l|}
\hline Mergers type & Numbers in 2004-2010 & Usable numbers & Year of mergers \\
\hline Two similar municipalities (a2) & 3 & 3 & $2006 ; 2006 ; 2008$ \\
\hline Three similar municipalities (a3) & 1 & & \\
\hline Four similar municipalities (a4) & 2 & & \\
\hline Two different municipalities (b2) & 4 & 2 & $2006 ; 2006$ \\
\hline Three different municipalities (b3) & 1 & & \\
\hline Four different municipalities (b4) & 3 & 3 & $2005 ; 2005 ; 2006$ \\
\hline Total & 14 & 8 & $2005,2006,2008$ \\
\hline
\end{tabular}

This study intended to use the data for all the municipalities and thus include all amalgamations during the relevant period, but since not all of the cost data was available for some of the smallest municipalities, only numbers for eight out of twelve possible amalgamations were present in the final version of the database. Most of them took place in 2006, two in 2005, and one in 2008. They covered amalgamations of three types: two similar municipalities (group a2), two different municipalities (group b2), and four different municipalities (group b4). Two amalgamations were in group b2 and three were in a2 and b4.

Table 3. Descriptive statistics of the models' variables.

\begin{tabular}{|l|l|l|l|l|l|l|}
\hline Variable & Description & $\begin{array}{l}\text { Obser- } \\
\text { vations }\end{array}$ & Average & $\begin{array}{l}\text { Standard } \\
\text { deviation }\end{array}$ & Min & Max \\
\hline Industrial affairs & $\begin{array}{l}\text { Inverse hyperbolic sine of the } \\
\text { industrial affairs' cost per capita in } \\
\text { each municipality and each year. }\end{array}$ & 516 & 9.44 & 1.83 & 0.00 & 12.82 \\
\hline Fire department & $\begin{array}{l}\text { Inverse hyperbolic sine of the fire } \\
\text { departments' cost per capita in each } \\
\text { municipality and each year. }\end{array}$ & 516 & 9.70 & 1.69 & -8.02 & 13.05 \\
\hline
\end{tabular}




\begin{tabular}{|c|c|c|c|c|c|c|}
\hline Social service & $\begin{array}{l}\text { Inverse hyperbolic sine of the } \\
\text { social services' cost per capita in } \\
\text { each municipality and each year. }\end{array}$ & 516 & 10.87 & 1.29 & 0.00 & 12.89 \\
\hline Education & $\begin{array}{l}\text { Inverse hyperbolic sine of } \\
\text { educational affairs' cost per capita } \\
\text { in each municipality and each year. }\end{array}$ & 516 & 13.11 & 1.33 & 0.00 & 14.14 \\
\hline Health & $\begin{array}{l}\text { Inverse hyperbolic sine of health } \\
\text { care's cost per capita in each } \\
\text { municipality and each year. }\end{array}$ & 516 & 3.77 & 3.89 & -7.23 & 10.21 \\
\hline Hygiene & $\begin{array}{l}\text { Inverse hyperbolic sine of } \\
\text { hygiene's cost per capita in each } \\
\text { municipality and each year. }\end{array}$ & 516 & 10.34 & 1.24 & 0.00 & 12.43 \\
\hline Culture & $\begin{array}{l}\text { Inverse hyperbolic sine of the } \\
\text { cultural cost per capita in each } \\
\text { municipality and each year. }\end{array}$ & 516 & 10.53 & 1.66 & 0.00 & 12.44 \\
\hline Overhead & $\begin{array}{l}\text { Inverse hyperbolic sine of the } \\
\text { overhead's cost per capita in each } \\
\text { municipality and each year. }\end{array}$ & 516 & 11.63 & 1.23 & 0.00 & 13.02 \\
\hline Planning & $\begin{array}{l}\text { Inverse hyperbolic sine of the } \\
\text { planning and construction's cost } \\
\text { per capita in each municipality and } \\
\text { each year. }\end{array}$ & 516 & 9.99 & 1.31 & 0.00 & 12.90 \\
\hline Transportation & $\begin{array}{l}\text { Inverse hyperbolic sine of } \\
\text { transportation's cost per capita in } \\
\text { each municipality and each year. }\end{array}$ & 516 & 9.78 & 1.88 & -6.54 & 11.83 \\
\hline Environment & $\begin{array}{l}\text { Inverse hyperbolic sine of } \\
\text { environmental issues' cost per } \\
\text { capita in each municipality and } \\
\text { each year. }\end{array}$ & 516 & 9.77 & 1.39 & 0.00 & 12.41 \\
\hline $\begin{array}{l}\text { Sports and youth } \\
\text { welfare }\end{array}$ & $\begin{array}{l}\text { Inverse hyperbolic sine of the } \\
\text { sports and youth welfare's cost per } \\
\text { capita in each municipality and } \\
\text { each year. }\end{array}$ & 516 & 11.03 & 2.16 & 0.00 & 13.01 \\
\hline Wages & $\begin{array}{l}\text { Inverse hyperbolic sine of the } \\
\text { municipalities average wages each } \\
\text { year. }\end{array}$ & 437 & 9.14 & 0.20 & 8.01 & 10.03 \\
\hline Population & $\begin{array}{l}\text { Inverse hyperbolic sine of the local } \\
\text { population in each municipality on } \\
\text { December } 1 \text { of each year. }\end{array}$ & 516 & 7.37 & 1.47 & 0.00 & 11.03 \\
\hline Distance & $\begin{array}{l}\text { Inverse hyperbolic sine of the } \\
\text { distance from Reykjavík from each } \\
\text { municipality on January } 1 \text { of each } \\
\text { year. }\end{array}$ & 516 & 5.76 & 1.24 & 1.82 & 7.28 \\
\hline Urban & Inverse hyperbolic sine of the & 516 & 0.87 & 0.62 & 0.00 & 2.31 \\
\hline
\end{tabular}




\begin{tabular}{|c|c|c|c|c|c|c|}
\hline & $\begin{array}{l}\text { number of urban communities in } \\
\text { each municipality on January } 1 \text { of } \\
\text { each year. }\end{array}$ & & & & & \\
\hline Geographical area & $\begin{array}{l}\text { Inverse hyperbolic sine of the } \\
\text { geographical area in square } \\
\text { kilometers in each municipality on } \\
\text { January } 1 \text { of each year. }\end{array}$ & 516 & 5.98 & 1.45 & 1.57 & 8.52 \\
\hline d2004 & Dummy variable for the year 2004 & 516 & 0.14 & 0.35 & 0.00 & 1.00 \\
\hline $\mathrm{d} 2005$ & Dummy variable for the year 2005 & 516 & 0.14 & 0.35 & 0.00 & 1.00 \\
\hline d2006 & Dummy variable for the year 2006 & 516 & 0.14 & 0.35 & 0.00 & 1.00 \\
\hline $\mathrm{d} 2007$ & Dummy variable for the year 2007 & 516 & 0.14 & 0.35 & 0.00 & 1.00 \\
\hline d2009 & Dummy variable for the year 2009 & 516 & 0.14 & 0.35 & 0.00 & 1.00 \\
\hline $\mathrm{d} 2010$ & Dummy variable for the year 2010 & 516 & 0.14 & 0.35 & 0.00 & 1.00 \\
\hline Mergers_a2 & $\begin{array}{l}\text { Dummy variable for the } \\
\text { amalgamation of two similar } \\
\text { municipalities }\end{array}$ & 516 & 0.03 & 0.16 & 0.00 & 1.00 \\
\hline Mergers_a3 & $\begin{array}{l}\text { Dummy variable for the } \\
\text { amalgamation of three similar } \\
\text { municipalities }\end{array}$ & 516 & 0.00 & 0.00 & 0.00 & 0.00 \\
\hline Mergers_a4 & $\begin{array}{l}\text { Dummy variable for the } \\
\text { amalgamation of four similar } \\
\text { municipalities }\end{array}$ & 516 & 0.00 & 0.00 & 0.00 & 0.00 \\
\hline Mergers_b2 & $\begin{array}{l}\text { Dummy variable for the } \\
\text { amalgamation of two different } \\
\text { municipalities }\end{array}$ & 516 & 0.02 & 0.14 & 0.00 & 1.00 \\
\hline Mergers_b3 & $\begin{array}{l}\text { Dummy variable for the } \\
\text { amalgamation of three different } \\
\text { municipalities }\end{array}$ & 516 & 0.00 & 0.00 & 0.00 & 0.00 \\
\hline Mergers_b4 & $\begin{array}{l}\text { Dummy variable for the } \\
\text { amalgamation of four different } \\
\text { municipalities }\end{array}$ & 516 & 0.03 & 0.18 & 0.00 & 1.00 \\
\hline
\end{tabular}

Source: From Authors database.

As mentioned earlier, it was tempting and necessary to estimate the changes of average cost regarding the economic crisis in 2008, since the expected income of many of the municipalities decreased and some of the expenditures increased because of the crisis, such as social affairs following increased unemployment and capital charges as a result of rising inflation. Thus, local governments were forced to cut expenses in other affairs to level off costs. In order to trace the effects, a dummy variable was constructed and given the value 0 for all observations except for the years of 2008, 2009, and 2010, during which all values were 1. By discarding the year 2008 in the estimation, it became a base year and the regression estimations for all other years represented the marginal difference from 2008. Thus, the values (and z-values) for 2009 and 2010 dummy variables reflected the dimension (and 
the significance) of the necessary retrenchments. Note, however, that a dummy variable of this kind in a panel data sample of annual averages is generally used to capture the possible influences of macro-economic factors on the dependent variable, such as inflation, economic growth, and interest rates.

The data for Reykjavík was discarded because it was an outlier, since Reykjavík is very populous compared to other municipalities and is thus a possible threat to heteroskedasticity. Observations for Akureyri were discarded as well, because cost values were missing in one of the municipalities that merged with Akureyri.

Table 3 expresses the sample statistics. The sample generates approximatelly 500 observations. The variation of the data seems to be sufficient when standard deviation is compared to the mean.

Table 4. Amalgamated municipalities during the period 2004-2010 on which the analysis was based

\begin{tabular}{|c|c|c|c|}
\hline $\begin{array}{l}\text { Amalgamated } \\
\text { municipality }\end{array}$ & Year of amalgamation & $\begin{array}{l}\text { Population after } \\
\text { amalgamation }\end{array}$ & $\begin{array}{l}\text { Amalgamated municipalities } \\
\text { (population when merger took } \\
\text { place) }\end{array}$ \\
\hline Borgarbyggð & 2005 & 3447 & $\begin{array}{l}\text { Borgarbyggð (2 593) } \\
\text { Borgarfjarðarsveit (670) } \\
\text { Hvítársíðuhreppur (84) } \\
\text { Kolbeinsstaðahreppur (100) }\end{array}$ \\
\hline Dalabyggð & 2006 & 715 & $\begin{array}{l}\text { Dalabyggð (638) } \\
\text { Saurbæjarhreppur (77) }\end{array}$ \\
\hline Fjallabyggð & 2006 & 2298 & $\begin{array}{l}\text { Ólafsfjarðarbær (946) } \\
\text { Siglufjarðarkaupstaður (1352) }\end{array}$ \\
\hline Fjarðabyggð & 2005 & 4137 & $\begin{array}{l}\text { Fjarðabyggð (3 175) } \\
\text { Mjóafjarðarhreppur (38) } \\
\text { Fáskrúðsfjarðarhreppur (51) } \\
\text { Austurbyggð (873) }\end{array}$ \\
\hline Langanesbyggð & 2006 & 542 & $\begin{array}{l}\text { Pórshafnarhreppur (417) } \\
\text { Skeggjastaðahreppur (125) }\end{array}$ \\
\hline Norðurping & 2006 & 3031 & $\begin{array}{l}\text { Húsavíkurbær (2 373) } \\
\text { Kelduneshreppur (100) } \\
\text { Öxarfjarðarhreppur (330) } \\
\text { Raufarhafnarhreppur (228) }\end{array}$ \\
\hline Strandabyggð & 2006 & 500 & $\begin{array}{l}\text { Hólmavíkurhreppur (447) } \\
\text { Broddaneshreppur (53) }\end{array}$ \\
\hline Pingeyjarsveit & 2008 & 942 & $\begin{array}{l}\text { Aðaldælahreppur (261) } \\
\text { Pingeyjarsveit (681) }\end{array}$ \\
\hline
\end{tabular}

Source: From Authors database.

\section{The Results}


It can be argued that an amalgamation of municipalities could lead to lower average cost. The analysis was based on a regression of a panel data model (model 4), which tested whether the average cost of the affairs of 8 different municipalities decreased significantly following their amalgamation.

Additional data was collected in order to improve an earlier study (Vífill Karlsson \& Jónsson, 2011-2012) based on a cross section analysis for almost all municipalities in Iceland in the year 2006. Now, the data sample covers a period of seven years (2004-2010) for almost all municipalities in Iceland. During this period, 12 municipal amalgamations took place, although data for only eight of them was available.

Table 5. The results of industrial, cultural, overhead, transportation, and environmental affairs. More reliable.

\begin{tabular}{|c|c|c|c|c|c|}
\hline Explanatory variables & Industries* & Culture* & Overhead & Transportation & Environment* \\
\hline Wages (IHS) & $0.62(2.15)$ & $0.13(1.45)$ & $0.14(2.79)$ & $0.11(0.30)$ & $0.20(1.52)$ \\
\hline Population (IHS) & $-1.45(-2.05)$ & $-0.06(-0.12)$ & $-0.26(-6.59)$ & $0.16(1.40)$ & $-1.61(-2.90)$ \\
\hline Distance (IHS) & $-0.10(-0.28)$ & $0.03(0.14)$ & $0.00(-0.10)$ & $0.02(0.21)$ & $-0.63(-2.51)$ \\
\hline Urban (IHS) & $-0.26(-1.63)$ & $-0.04(-0.28)$ & $0.14(1.90)$ & $0.75(1.82)$ & $0.07(0.50)$ \\
\hline Geographical area (IHS) & $-0.04(-0.32)$ & $0.08(0.89)$ & $0.01(0.56)$ & $-0.20(-2.44)$ & $-0.24(-2.16)$ \\
\hline $\mathrm{d} 2004$ & & & & $-0.49(-4.63)$ & \\
\hline $\mathrm{d} 2005$ & & $-0.07(-1.61)$ & $-0.09(-3.83)$ & $-0.35(-3.51)$ & $-0.24(-3.75)$ \\
\hline $\mathrm{d} 2006$ & $-0.24(-1.81)$ & $-0.07(-1.70)$ & $-0.03(-1.65)$ & $-0.57(-2.90)$ & $-0.20(-4.16)$ \\
\hline $\mathrm{d} 2007$ & $-0.14(-0.97)$ & $-0.05(-1.16)$ & $0.02(1.17)$ & $-0.37(-3.26)$ & $-0.08(-1.47)$ \\
\hline d2009 & $0.03(0.21)$ & $-0.07(-1.69)$ & $-0.09(-4.59)$ & $0.04(0.38)$ & $-0.08(-1.71)$ \\
\hline $\mathrm{d} 2010$ & $0.10(0.84)$ & $-0.10(-1.97)$ & $-0.06(-3.30)$ & $-0.26(-1.42)$ & $-0.21(-4.03)$ \\
\hline Mergers_a2 & $-0.40(-2.25)$ & $0.31(3.82)$ & $0.17(3.10)$ & $0.11(0.54)$ & $-0.04(-0.33)$ \\
\hline Mergers_b2 & $-0.22(-1.19)$ & $0.09(0.49)$ & $-0.04(-0.35)$ & $0.33(1.52)$ & $0.04(0.33)$ \\
\hline Mergers_b4 & $-0.53(-2.53)$ & $-0.24(-2.10)$ & $-0.08(-0.78)$ & $-0.03(-0.22)$ & $0.14(1.24)$ \\
\hline $\begin{array}{l}\text { Lagged residual by one } \\
\text { period of time }\end{array}$ & $-0.11(-0.38)$ & $0.39(2.88)$ & $0.21(3.45)$ & & $0.34(3.73)$ \\
\hline $\begin{array}{l}\text { Lagged residual by two } \\
\text { periods of time }\end{array}$ & $0.55(2.10)$ & & & & \\
\hline \multicolumn{6}{|l|}{$\begin{array}{l}\text { Lagged residual by three } \\
\text { periods of time }\end{array}$} \\
\hline Constant & $16.23(2.04)$ & $9.47(1.72)$ & $12.33(19.42)$ & $8.42(2.16)$ & $25.62(4.20)$ \\
\hline Within $\mathrm{R}^{2}$ & 0.1023 & 0.1601 & 0.2346 & 0.0584 & 0.1642 \\
\hline Between $\mathrm{R}^{2}$ & 0.6225 & 0.1510 & 0.6174 & 0.3106 & 0.2791 \\
\hline Overall $\mathrm{R}^{2}$ & 0.5292 & 0.1544 & 0.5879 & 0.1961 & 0.2462 \\
\hline Observations (n) & 305 & 369 & 369 & 437 & 369 \\
\hline Woldridge t-test & 1.35 & -1.69 & -0.46 & -2.68 & 0.11 \\
\hline Former Hausman Chi-sq. test & 19.8 & 9.32 & 7.43 & 2.92 & 7.19 \\
\hline Latter Hausman Chi-sq. Test & 8.47 & 13.6 & 16.00 & 2.46 & 2.13 \\
\hline
\end{tabular}




\begin{tabular}{|l|r|r|r|r|r|}
\hline Wages (IHS) & $0.62(2.15)$ & $0.13(1.45)$ & $0.14(2.79)$ & $0.11(0.30)$ & $0.20(1.52)$ \\
\hline Population (IHS) & $-1.45(-2.05)$ & $-0.06(-0.12)$ & $-0.26(-6.59)$ & $0.16(1.40)$ & $-1.61(-2.90)$ \\
\hline Distance (IHS) & $-0.10(-0.28)$ & $0.03(0.14)$ & $0.00(-0.10)$ & $0.02(0.21)$ & $-0.63(-2.51)$ \\
\hline
\end{tabular}

Source: Research findings. * The explanatory variable population was endogeneous. Gender ratio and average age implemented as instruments. The critical value of the Hausman test was 22.12 (Passed if lower) The former Hausman test was for the initial version of the model and the latter for the final version of the model. The dependent variable was the relevant affairs operation cost per capita (IHS).

IHS = Inverse hyperbolic sine. The IHS of each value was calculated. The natural logarithm was replaced by IHS.

Multicollinearity was not detected. Serial correlation was not present following some model adjustments in all analyses except one - transportation. Since heteroskedasticity was present in all models, robust estimates were implemented. The presence of endogeneity was tested against population and wages and detected in a couple of instances against population (noted by * in tables' head). Gender ratio (women/men) and average age were used as instruments in cases in which it seemed likely that they would correlate with population and not the residuals. Population tends to be lower in communities where women number fewer than men, thus affecting the gender ratio. Average age seems to be higher in smaller communities. It is also reasonable to argue that wages are higher in communities where women number fewer than men and where average age is lower.

Table 6. The results of social service, education, health, hygiene, planning, sports, and youth welfare. Less reliable.

\begin{tabular}{|l|r|r|r|r|r|}
\hline Explanatory variables & Social service & Education* & Health & Hygiene & Planning \\
\hline Wages (IHS) & $0.00(0.01)$ & $-0.01(-0.17)$ & $0.64(0.94)$ & $0.55(3.60)$ & $0.29(1.66)$ \\
\hline Population (IHS) & $0.20(2.09)$ & $0.16(1.05)$ & $1.03(1.59)$ & $-0.25(-6.68)$ & $-0.26(-3.72)$ \\
\hline Distance (IHS) & $0.14(1.38)$ & $0.09(1.23)$ & $1.46(2.56)$ & $0.05(1.60)$ & $-0.27(-4.57)$ \\
\hline Urban (IHS) & $0.11(1.20)$ & $-0.07(-1.40)$ & $-2.04(-1.86)$ & $0.00(-0.04)$ & $0.53(3.69)$ \\
\hline Geographical area (IHS) & $0.01(0.24)$ & $0.06(2.17)$ & $0.02(0.07)$ & $0.09(4.45)$ & $0.05(1.43)$ \\
\hline d2004 & $-0.11(-2.05)$ & & & & \\
\hline d2005 & $-0.12(-2.40)$ & & $-0.38(-1.12)$ & & $-0.20(-2.80)$ \\
\hline d2006 & $-0.24(-1.61)$ & & $-0.17(-0.53)$ & & $-0.20(-2.62)$ \\
\hline d2007 & $0.00(-0.02)$ & $0.00(0.04)$ & $-0.21(-0.71)$ & $-0.04(-0.68)$ & $-0.11(-1.75)$ \\
\hline d2009 & $0.06(1.32)$ & $-0.03(-3.56)$ & $-0.25(-0.92)$ & $0.02(0.32)$ & $-0.14(-2.35)$ \\
\hline d2010 & $0.09(1.72)$ & $-0.04(-4.15)$ & $-0.45(-1.63)$ & $0.08(1.45)$ & $-0.28(-4.37)$ \\
\hline Mergers_a2 & $-0.08(0.75)$ & $0.01(0.24)$ & $1.58(1.42)$ & $-0.08(-0.75)$ & $0.43(2.34)$ \\
\hline Mergers_b2 & $-0.05(-0.32)$ & $0.02(0.26)$ & $-0.28(-0.3)$ & $-1.56(-5.28)$ & $0.16(1.11)$ \\
\hline Mergersb4 & & $-0.27(-0.84)$ & $0.16(1.38)$ & $-0.60(-2.65)$ & $0.38(4.58)$ \\
\hline $\begin{array}{l}\text { Lagged residual by one } \\
\text { period of time }\end{array}$ & & $-2.03(-1.93)$ & & $-1.44(-2.45)$ & \\
\hline $\begin{array}{l}\text { Lagged residual by two } \\
\text { periods of time }\end{array}$ & & & & & \\
\hline
\end{tabular}




\begin{tabular}{|l|r|r|r|r|r|}
\hline $\begin{array}{l}\text { Lagged residual by three } \\
\text { periods of time }\end{array}$ & & $2.71(2.02)$ & & $2.16(4.59)$ & \\
\hline Constant & $8.56(5.57)$ & $11.37(6.86)$ & $-16.11(-1.55)$ & $6.60(4.71)$ & $10.28(6.19)$ \\
\hline & & & & & \\
\hline Within $\mathrm{R}^{2}$ & 0.0418 & 0.3358 & 0.0727 & 0.0121 & 0.2100 \\
\hline Between R $\mathrm{R}^{2}$ & 0.2887 & 0.1855 & 0.1199 & 0.7697 & 0.2833 \\
\hline Overall R $\mathrm{R}^{2}$ & 0.1744 & 0.2158 & 0.1011 & 0.6696 & 0.2531 \\
\hline Observations (n) & 437 & 242 & 369 & 242 & 369 \\
\hline Woldridge t-test & -0.26 & -1.92 & -1.74 & -0.75 & -0.69 \\
\hline Former Hausman Chi-sq. test & 1.66 & 20.54 & 15.95 & 9.83 & 22.12 \\
\hline Latter Hausman Chi-sq. Test & 35.82 & Not testable & Not testable & Not testable & 27.43 \\
\hline Wages (IHS) & $0.00(0.01)$ & $-0.01(-0.17)$ & $0.64(0.94)$ & $0.55(3.60)$ & $0.29(1.66)$ \\
\hline Population (IHS) & $0.20(2.09)$ & $0.16(1.05)$ & $1.03(1.59)$ & $-0.25(-6.68)$ & $-0.26(-3.72)$ \\
\hline Distance (IHS) & $0.14(1.38)$ & $0.09(1.23)$ & $1.46(2.56)$ & $0.05(1.60)$ & $-0.27(-4.57)$ \\
\hline
\end{tabular}

Source: Research findings. * Local population was endogeneous. Gender ratio and average age implemented as instruments. The critical value of the Hausman test was 22.12 (Passed if lower) The former Hausman test was for the initial version of model and the latter for the final version of the model. The dependent variable was the relevant affairs operation cost per capita (IHS). IHS = Inverse hyperbolic sine. The IHS of each value was calculated. The natural logarithm was replaced by IHS.

The results are presented in two tables: More reliable results in the former (Table 5) and less robust and reliable results in the latter (Table 6). The Hausman test suggested the implementation of a random effect model instead of the fixed-effect model.

The results were reliable for industrial affairs, culture, overhead, transportation, and environment (Table 5). They suggest that the average cost of industrial affairs and culture decreased following the amalgamation of four different municipalities. Moreover, the average cost of industrial affairs decreased significantly for the amalgamations of two similar municipalities. The analysis shows, however, that average cost increased for culture and overhead when two similar municipalities merged.

Other less-reliable estimations suggest that the cost of social services has decreased following the amalgamation of two different municipalities and that of hygiene and sports and youth welfare when four different municipalities merged (Table 6). However, the cost of running sports and youth welfare seemed to have increased following an amalgamation of two different municipalities and planning and construction when two similar municipalities merged.

Accordingly, the benefit seems to be greatest in the case of the amalgamation of many and different municipalities. In other cases with few and similar municipalities, a potential benefit in one affair seems to be spent in another.

The results revealed some other interesting issues as well. The relationshiip between average cost and local population was found to be negative in the cases of overhead and industrial and environmental affairs. This implies scale economies even though we are not using the stochastic frontier model. However, the cost for social services and sports and youth welfare returned the opposite relationship; that is cost increased following a population increase. That 
implies scale diseconomies.

The results suggest that cost decreased following the economic crash in 2008 in overheadand cultural and environmental affairs. The cut was relatively largest in environmental affairs followed by cultural affairs and the least in overhead. There is also evidence - weaker, however, - of decreased cost in education and planning following the crash.

The cost of environmental affairs decreased significantly the farther away the community was from Reykjavík and the same applies to planning, while health care cost increased. Note that municipal expenses for health care in Iceland only cover health surveillance. The central government runs hospitals and health care centres.

According to the results, the number of urban areas within each municipality positively affected the average cost of culture, overhead, transport, planning, sports and youth welfare.

Furthermore, the average cost of transport and environmental affairs was significantly lower in geographically larger municipalities. Sports and youth welfare showed similar trends. Oddly, education, however, was significantly more expensive in the larger municipalities. This is related to the fact that the level of service provided for education is more strictly defined than in the other three affairs.

As referred to above, the overall results suggest that amalgamation of municipalities is more likely to lead to reduced average cost if there are many different municipalities involved than if they are fewer and similar. Furthermore, it is most likely that the benefit - in terms of average cost reduction - will be generated in industrial and cultural affairs.

\section{Discussion}

These results are not in line with fairly recent results for Iceland (Vífill Karlsson \& Jónsson, 2011-2012) implemented by another method and database which suggested that amalgamation would most likely lead to the decreased average cost of overhead. The present results certainly suggest that overhead average cost would decrease following an increased local population but not following municipal amalgamations. In one case - two similar municipalities - the average cost of overhead would increase by $17 \%$ following an amalgamation. This reflects the methodological problem of the prior study (Vífill Karlsson \& Jónsson, 2011-2012), for which the impact of the population development on average cost is estimated without distinguishing between traditional reasons (migration and birth and death rates) and municipal amalgamation. The present method - one that separates the different origins of population development - suggests that the average cost of orverhead would not decrease following municipal amalgamations.

It is, however, worrisome that the two affairs that would most likely decrease following an amalgamation, industrial and cultural affairs, only generate approximately 5\% of total municipal expenses - cultural affairs $4.1 \%$ and industrial affairs $1.0 \%$. Thus, municipal amalgamations appear to return a rather limited benefit in terms of operating cost only.

Note that the present study only accounts for operating cost and not for level of service. It is possible that local government was able to cut expenditures following a municipal 
amalgamation in the peripheries that caused increased spatial disparity at service level. If, for example, a small and a large municipality merge, the administration of the large municipality will probably be able to run the administration of the small one without hiring new workers. This, however, is not plausible when two similar municipalities amalgamate, in which case it is likely that the voters would ask for an administration office in both former municipalities. This might partly be the explanation for the results of Grétar Eypórsson and Hjalti Jóhannesson (2002, p. 261), who found that the inhabitants of similar municipalities were more pleased with the results of a recent amalgamation than were those living in different municipalities. It would be interesting to run a survey in the eight municipalities of the present study in which the inhabitants would be asked to describe changes in municipality service levels following the amalgamation.

\section{Summary}

The present study investigated whether the average cost of municipality services, classified by 11 different affairs, has decreased following an amalgamation. Most previous studies have addressed comparable questions by investigating the scale economies of municipalities. It has been documented that scale economies exist in some of the municipal affairs. The present study argued that a traditional analysis of scale economies does not necessarily capture the real impact on average cost of municipal amalgamation. It does, however, capture the impact of population changes on average cost, but not when these occur as a result of municipal amalgamation and do not include changes in population density. Therefore, the present study approaches the question at hand by implementing dummy variables that are switched following a municipality amalgamation along with other significant explanatory variables, such as local population, geographical size municipalities, number of urban communities, and the distance from the capital city, applied as continuous variables. The results suggest that average cost has decreased in several municipal affairs following an amalgamation. The analysis was based on a panel data sample from almost all municipalities in Iceland during the period of 2004-2010, including eight amalgamations, with a special focus on industrial and cultural affairs. These two affairs account for about $5 \%$ of total municipal expenditures. Note that overhead cost was not affected by municipal amalgamation, as suggested by a similar recent study for Iceland (Vífill Karlsson \& Jónsson, 2011-2012).

\section{References}

Blesse, S., \& Baskaran, T. (2013). Do municipal mergers result in scale economies? Evidence from a German federal state. Discussion Papers, Center for European Governance and Economic Development Research, 176, 1-46.

Blom-Hansen, J. (2010). Municipal Amalgamations and Common Pool Problems: The Danish Local Government Reform in 2007. Scandinavian Political Studies, 33(1), 51-73. http://dx.doi.org/10.1111/j.1467-9477.2009.00239.x

Blom-Hansen, J., Houlberg, K., \& Serritzlew, S. (2011). Scale effects in local government? evidence from local government amalgamations in Denmark. Unpublished paper presented at the XX NORKOM conference, November 2011, Gothenburg, Sweden. 


\section{Macrothink Institute ${ }^{\mathrm{TM}}$}

Breyting á sveitarfélagaskipan á Íslandi frá 1950. (2012). Retrieved 16.08, 2012, from http://www.samband.is/verkefnin/skipulags--og-byggdamal/sameining-sveitarfelaga/

Burridge, M. (2008). Scale and efficiency in the provision of local government services. International Journal of Business Performance Management, 10(1), 9. http://dx.doi.org/10.1504/IJBPM.2008.015923

Byrnes, J., \& Dollery, B. (2002). Do Economies of Scale Exist in Australian Local Government? A Review of the Research Evidence. Urban Policy and Research, 20(4), 391-414. http://dx.doi.org/10.1080/0811114022000032618

Dahl, R. A. (1967). The city in the future of democracy. The American Political Science Review, 61(4), 17. http://dx.doi.org/10.2307/1953398

Dollery, B., Byrnes, J., \& Crase, L. (2007). Is Bigger Better? Local Government Amalgamation and the South Australian Rising to the Challenge Inquiry. Economic Analysis and Policy, 37(1), 14. http://dx.doi.org/10.1016/S0313-5926(07)50001-9

Dollery, B., Crase, L., \& Johnson, A. (2006). Australian Local Government Economics The Economic Record, The Economic Society of Australia. Sidney: UNSW Press.

Duncombe, W., Miner, J., \& Ruggiero, J. (1995). Potential cost savings from school district consolidation: A case study of New York. Economics of Education Review, 14(3), 265-284. http://dx.doi.org/10.1016/0272-7757(94)00011-T

Duncombe, W., \& Yinger, J. (2007). Does School District Consolidation Cut Costs? Education Finance and Policy, 2(4), 341-375. http://dx.doi.org/10.1162/edfp.2007.2.4.341

Dur, R., \& Staal, K. (2008). Local public good provision, municipal consolidation, and national transfers. Regional Science and Urban Economics, 38(2), 160-173. http://dx.doi.org/10.1016/j.regsciurbeco.2008.01.005

Eypórsson, G. P. (1998). Kommunindelningspolitik i Island: staten, kommunerna och folket om kommunsammanslagningar. (Ph.D.), Göteborgs universitet, Göteborg.

Eypórsson, G. P., Glösen, E., \& Karlsson, V. (2014). West Nordic municipal structure: Challenges to local democracy, efficient service provision and adaptive capacity.

Eypórsson, G. P., \& Jóhannesson, H. (2002). Sameining sveitarfélaga: Áhrif og afleiðingar. Rannsókn á sjö sveitarfélögum. Akureyri: Rannsóknarstofnun Háskólans á Akureyri.

Fox, W. F., \& Gurley, T. (2006). Will Consolidation Improve Sub-National Governments? World Bank Policy Research Working Paper, 3913, 1-45.

Heathfield, D. F., \& Wibe, S. (1987). An Introduction to Cost and Production Functions. London: MacMillan Education.

Houlberg, K. (2011). Administrative stordriftsfordele ved kommunalreformen i Danmark sandede eller tilsandede. Scandinavian Journal of Public Administration, 15(1), 20.

Jordahl, H., \& Liang, C.-Y. (2010). Merged municipalities, higher debt: on free-riding and the 
common pool problem in politics. Public Choice, 143, 16. http://dx.doi.org/10.1007/s11127-009-9495-y

Jónsson, G., \& Magnússon, M. S. (1997). Hagskinna. Reykjavík: Statistics Iceland.

Karlsson, V. (2011). The Relationship of Housing Prices and Transportation Improvements: Location and Marginal Impact. Spatial Economic Analysis, 6(2), 223-241. http://dx.doi.org/10.1080/17421772.2011.557774

Karlsson, V. (2012). Transportation improvement and interregional migration. (Ph.D.), University of Iceland, Reykjavik.

Karlsson, V., \& Jóhannesson, T. (2014). Sameiningar sveitarfélaga á Vesturlandi: Möguleikar nokkurra valkosta og hugsanleg áhrif peirra árið 2014 Skýrsla SSV (Vol. 3, pp. 1-121): Samtök sveitarfélaga á Vesturlandi.

Karlsson, V., \& Jónsson, E. Á. (2011-2012). Meðalkostnaður íslenskra sveitarfélaga, fjöldi íbúa og sameining sveitarfélaga. Bifrost Journal of Social Science, 5-6, 73-85.

Kristinsson, G. H. (2001). Staðbundin stjórnmál. Reykjavík: Háskólaútgáfan.

Lüchinger, S., \& Stutzer, A. (2002). Skalenerträge in der öffentlichen Kernverwaltung: eine empirische Analyse anhand von Gemeindefusionen. Swill Political Science Review, 8, 27-50. http://dx.doi.org/10.1002/j.1662-6370.2002.tb00333.x

Moisio, A. (2013). The impact of municipal merger on local public expenditures in Finland. Public Finance \& Management, 13(3), 148-166.

Nakazawa, K. (2013). Amalgamation, free-ride behavior, and regulation. Joint Discussion Paper Series in Economics, 29, 1-16.

Newton, K. (1982). Is small really so beautiful? Is big really so ugly? Size, effectiveness, and democracy in local government. Political Studies, 30(2), 190-206. http://dx.doi.org/10.1111/j.1467-9248.1982.tb00532.x

Nielsen, P. (2003). Kommunindelning och demokrati: Om sammanläggning och delning av kommuner i Sverige. Uppsala: Acta Universitatis Upsaliensis.

O'Sullivan, A. (2009). Urban economics (7th ed.). New York: McGraw-Hill / Irwin.

Reingewertz, Y. (2012). Do municipal amalgamations work? Evidence from municipalities in Israel. Journal of Urban Economics, 72(2-3), 240-251. doi: http://dx.doi.org/10.1016/j.jue.2012.06.001

Rosen, H. S., \& Gayer, T. (2008). Public Finance (8th ed.). New York: McGraw-Hill/Irwin. http://dx.doi.org/10.1007/978-0-387-75870-1_22

Rouse, P., \& Putterill, M. (2005). Local government amalgamation policy: A highway maintenance evaluation. Management Accounting Research, 16(4), 438-463. http://dx.doi.org/10.1016/j.mar.2005.07.003 


\section{Macrothink}

International Journal of Regional Development ISSN 2373-9851 2015, Vol. 2, No. 1

Schure, P., \& Wagenvoort, R. (1999). Economies of Scale and Efficiency in European Banking: New Evidence. Economic and Financial Report. Luxemburg: European Investment Bank.

Snævarr, S. (1993). Haglýsing Íslands. Reykjavík: Heimskringla.

Tyrefors Hinnerich, B. (2009). Do merging local governments free ride on their counterparts when facing boundary reform? Journal of Public Economics, 93(5-6), 721-728. http://dx.doi.org/10.1016/j.jpubeco.2009.01.003

Varian, H. R. (1992). Microeconomic Analysis. New York: W.W. Norton \& Company.

\section{Copyright Disclaimer}

Copyright for this article is retained by the author(s), with first publication rights granted to the journal.

This is an open-access article distributed under the terms and conditions of the Creative Commons Attribution license (http://creativecommons.org/licenses/by/3.0/). 